\title{
ばんぐ菌トもるた熱菌トノ血淸反應 上ノ異同二就テ
}

\section{二 村 崖 治 郎}

\section{（農商揫省獸疫調查所）}

\section{I. 緒 言}

ばんぐ菌卜ハ1896年 Bang \& Stribolt 雨氏二依テ牛, 流産胎兒ョリ發見セラレシ 細菌习意味シ又も万け熱菌卜ハ1887 年Bruce =依テ地中海熱二傳染シテ死亡セル兵士 ，脾藏ヨり發見セラレシ所謂 Micrococcus melitensis ヨ云つ1914 年 Kennedy 八るるた 熱菌ト山羊乳卜，凝集反應，賽驗中對照二使用七ル牛乳，陽性反潐习呈セシ二氧付キ

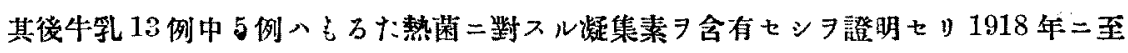
リE. Evans 八流產菌二關ス儿研究中該菌八形態生物學的性質及血清反應二於 け熱菌ト殆ンド相ー致スルヨ觀察シ更二此等, 細菌へB. bronchisepticus ト近似セ ルモノナリト云へリ1920年 Meyer \& Shaw 及 Feusier \& Neger 八E. Enans，

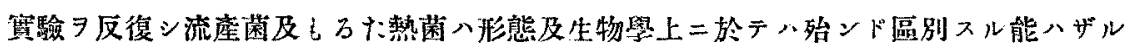

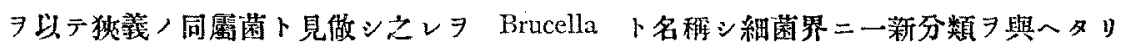
而シテ B. bronchisepticus ト八種々,性質二於テ相罢レルタ指摘シ前實驗者，誤り

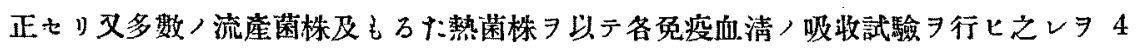
群二分類シ免疫血清中二有スル凝集素八同一群，菌栋ニテ八全部 ヨ吸收シ得ルモ他群

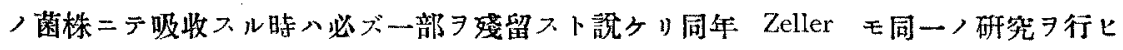
前者，賽驗成績

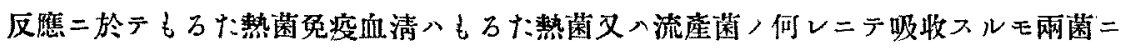

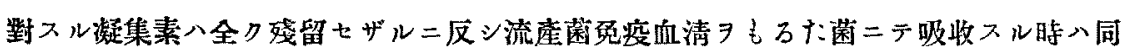

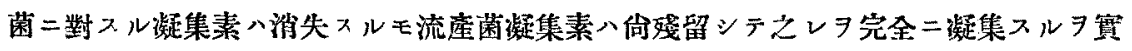
シもるた熱菌八流産菌，亞系株ナリト報告シ又1922年 Skaric 八も万け热菌免染血 清及流產菌免浚血清八各同名菌格二對シテ高度二凝集反應

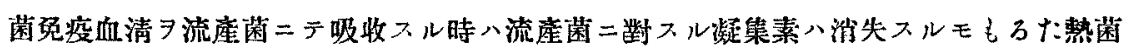

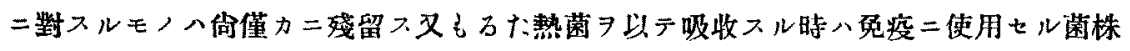

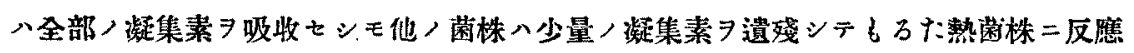
ヨ呈ス然レドモ流座菌二對シテへ全然陰性ナり又流虐菌免疫血清八免疫二使用七ル菌 
株ニテ吸收スル時八全部，凝集素习吸收スルモ其他，流座菌株及しろけ热囷二テ吸收 スル時ハ一部ノ凝集素 7 殘留ス仍テ此ノ事惯ニョリ氏八兩菌ノ凝集原八單一ナル性留 ニアラプシテ部分的凝集原 7 構成スルモノナリト，假說 $ヨ$ 示七り

以上ノ實驗成績二示ス如ク流産菌及しるた熱菌八形热及生物學的性質二於テ相一致 スルモ血清反應殊二吸收反應二於テ雨菌間二多少，差異 ヨ示スハ均シク認ムル所ナル モ其結果へ賽驗者ニョり全然相一致スルモノニアラズ

余ハ渡歐中ノ中村博士ヨリもるた熱菌及豚流產菌(Bang)，贈與

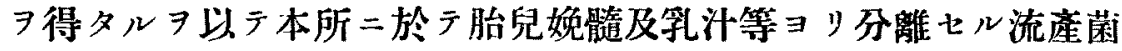

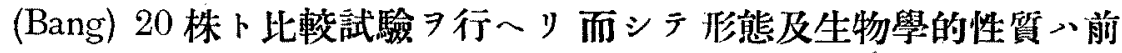
研究者ノ得タル成績ト㱠ンド一致スルモ血清反應二於テ兩菌，關 係ヨ極メテ明カニスルコトヨ得タリト信ズ仍テ其成績ノ概要 載スベシ

\section{II. 實驗方法}

1. 免疫血清 體重 $2000 \mathrm{~g}$. 内外，家鬼

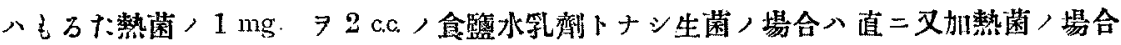

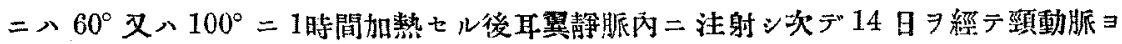
り血液习探取セり血清八小試驗管二入レ冰室二保存シテ隨時使丹セり而シテ血清ハ各 注射菌，名 $\exists$ 附 シ生 $60^{\circ}$ 又八 $100^{\circ}$ 加熱菌血清卜穫又

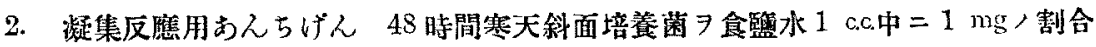

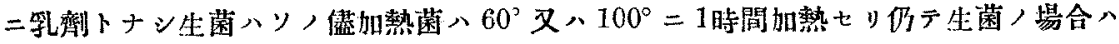
生む己ちげん加熱菌，場合八 $60^{\circ}$ 又八 $100^{\circ}$ おんちげス卜程ス

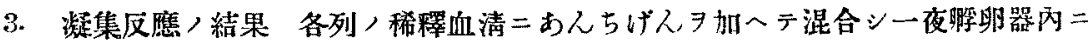
静置セル後觀察セリ

4. 凝集素八吸收方法 目的トスル血清 710 倍二稀釋シ之レニ中試驗管寒天斜面二

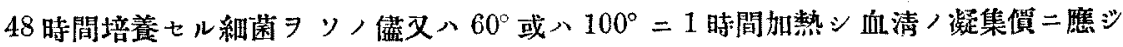

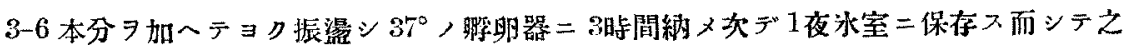
レヨ遠心器二裝シ透明トナシタル後使用セリ

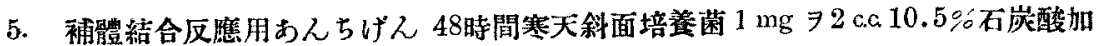

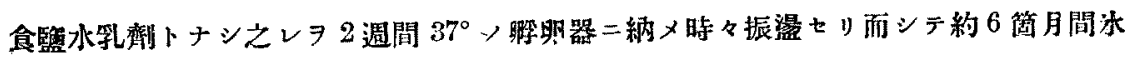


室二眝藏スル時へ菌體へ全ク容器ノ底二洮澱ン上液へ州黄色透明トナレリ實驗ニへ透 明液 7 使用 $x$

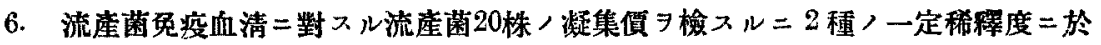
テ反應习呈シ此等八菌株八各凝集㵋 ヨリ 2 群二分類スルコトラ得タり仍テ其代表卜シ テ第 1 群 $ヨ$ り第 72 胎兒菌第 2 群 $\exists$ リ第 90 胎兒菌 7 選へリ而シテ後者八前者二比シ 稍了强キ凝集價 $\exists$ 有

\section{III. 凝集反應}

(a)生菌克疫血清卜生わんちげんニテ行へル場合 其成績い次表, 如 シ

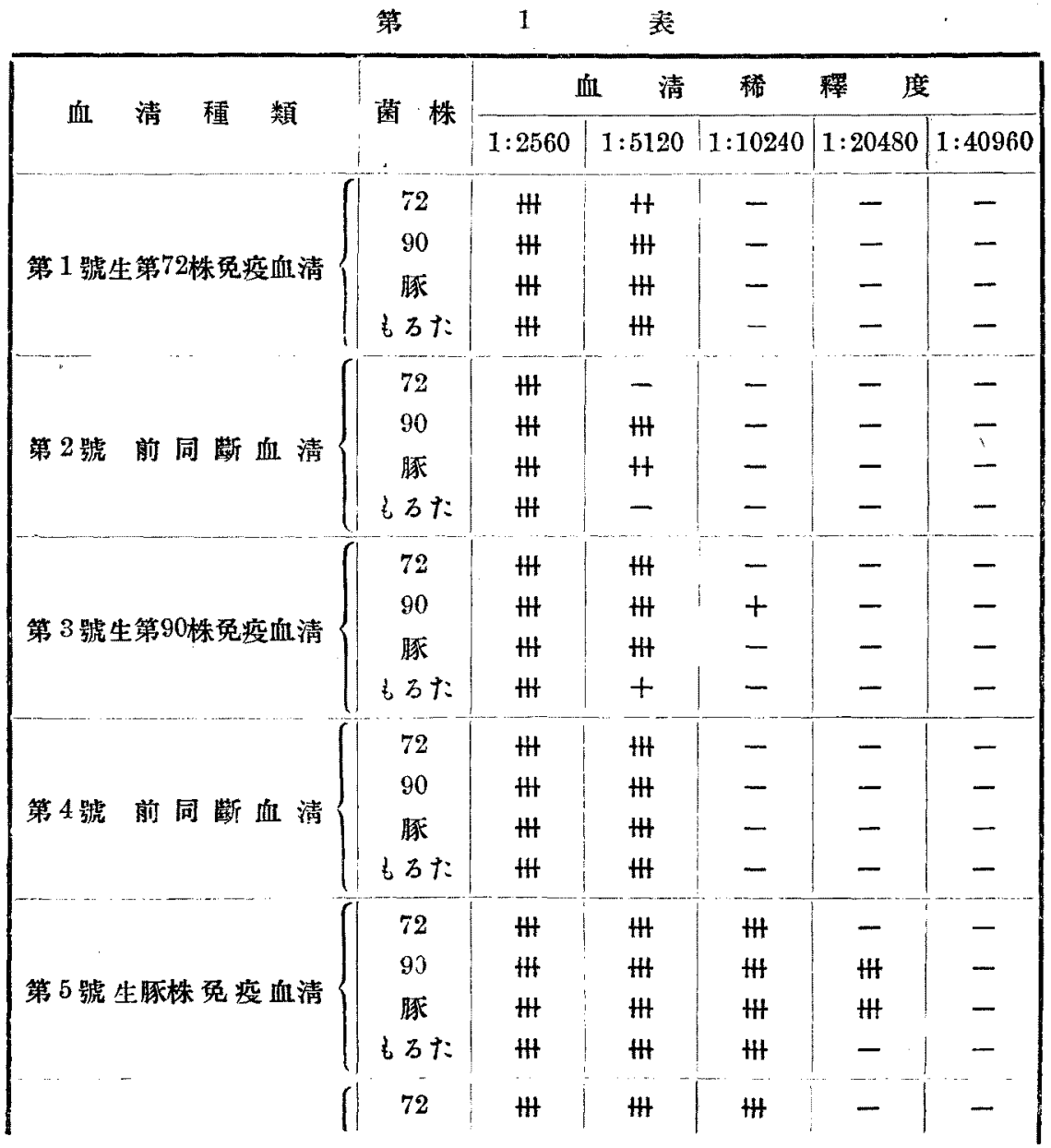




\begin{tabular}{|c|c|c|c|c|c|c|}
\hline \multirow{3}{*}{ 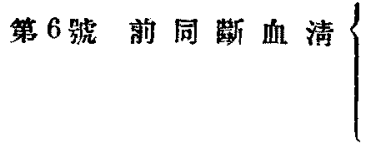 } & 90 & 世 & H & H & tt & - \\
\hline & 豚 & HI & \# & H & $H$ & - \\
\hline & もるた & H & 世 & $\mathrm{Ht}^{\circ}$ & - & - \\
\hline \multirow{4}{*}{ 第7號生もろた菌免疫血清 } & 72 & H & $\mathrm{H}$ & $\mathrm{HH}$ & - & - \\
\hline & 90 & H & H\# & H & - & - \\
\hline & 豚 & H & 世 & H & - & - \\
\hline & もろた & H & H & H & - & - \\
\hline \multirow{4}{*}{ 第 8 號 前 同 斷血 清 \{} & 72 & $H$ & H & - & - & $\div$ \\
\hline & 90 & H & 世 & $H$ & - & - \\
\hline & 豚 & 世 & Ht & + & - & - \\
\hline & もるた & H & $H$ & - & 一 & - \\
\hline
\end{tabular}

上表二示ス如ク 4 菌株ニテ免疫セル8 種血清中第 1-4 號及第 8

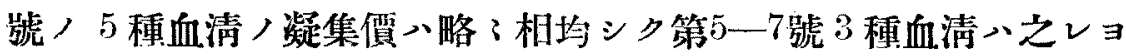

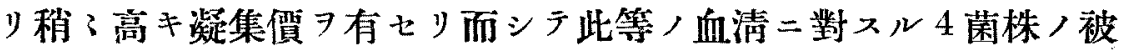
凝集性入第90株及豚株小他株二比シ稍 : 强夕もるて菌及第72株》 殆ンド相一致セり郎チ生血清二於ケル流產菌及るるて熱菌，凝集 價二八認ム可キ差異习證明スル能ハザリキ

一般二細菌凝集原入熱二對シテ種々ノ憔質ヨ有スルハ古クョリ 多數ノ學者ニヨリ研究セラル・所ニシラ郎テ1897年 Widal \& Sicard ハちふす菌 $770^{\circ}=$ 加熱スル時心疑集性 $尹$ 失フト言七 Joos

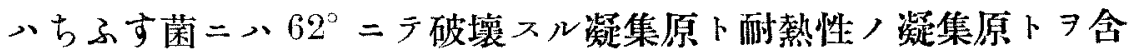

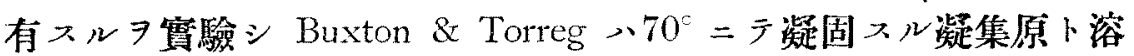
解スル凝集原卜ヨ得此, 雨種ノ凝集原い各: 異ナル凝集素习產生 スルトナシ Widal \& Sicard, Van de Velde, 及 Eisenberg \& Volk 等ハちふす菌 7 暂時 $100^{\circ}=$ 熱七バ其凝集原》永久的二消失スルト ナミ Porges ハ同溫度二長時間熱セバ再ビ疑集作用ヨ受クルニ至 ル下云フ爾來多數ノ學者ニヨリ實驗七ラレ我國二於ラモ最近渡邊

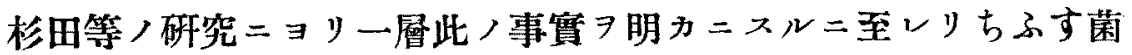
以外 ニこれら菌ぱらちふす菌赫琡菌及其他ノ細菌二於テ又非耐熱 
性及耐熱性ノ2 種ノ凝集原ヨ有スルハ廣ク證明セラル・所ナリ流 產菌及まるけ熱菌, 凝集原ノ性質二關シテハ未ダ報告 ヨ見ザルタ 以テ兩菌ガ熱二對シ單一ナル性質 行一y

（b 生免疫血清卜 $60^{\circ}$ 又、 $100^{\circ}$ おんちげんトニテ行へル 場合

其成績い次表ノ如シ

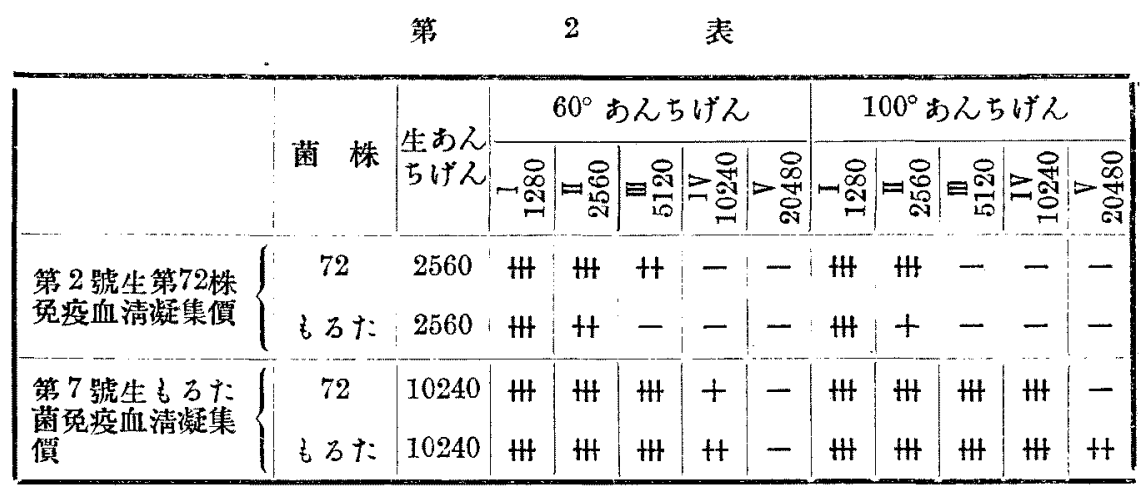

上表二示入如少第 2 號血清二對スル被凝集性》第 72 株 $100^{\circ}$ あ んちげんハ生菌ノ場合ト一致スルモ $60^{\circ}$ おんちげん》稍 、增加セ リ又もるて菌二於テ 、生菌二比シ加熱菌, 被凝集性》僅少ノ減退 ヨ示セり第 7 號血清二對スル加熱菌ノ被凝集性ハ生菌卜均シキカ 又心生菌ヨリモ稍 :增加セシモ兩株菌閒二八差異 7 認メげリキ

もるた熱菌、 $60^{\circ}$ 又、 $100^{\circ}$ 1時間，加熱二ヨリ流產菌血清二對 シ幾分被凝集性 7 減少スル事實ヨリシテ之レヨ種々ノ溫度二加熱 七バ顯著ナル差異ヨ示スコトナキャヨ考一あんちげん $760^{\circ} 80^{\circ}$ 及

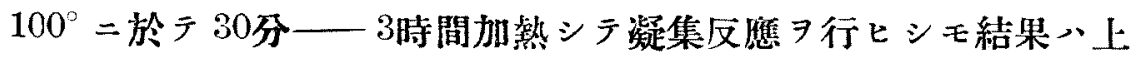
表二示ス成績卜差異ナカリキ次二加熱菌ヨ造抗原二使用シテ造レ ル血清ノ凝集價

(c) 加熱菌免疫血清卜生 $60^{\circ}$ 及 $100^{\circ}$ あんちげんト二テ行 
ヘル場合

其成績 次表ノ如シ

\begin{tabular}{|c|c|c|c|c|c|c|c|c|c|}
\hline 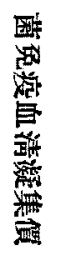 & 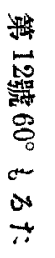 & 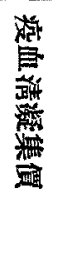 & 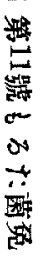 & 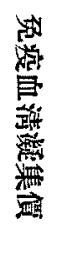 & 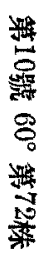 & 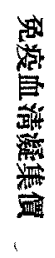 & 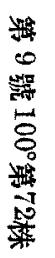 & 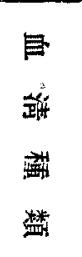 & 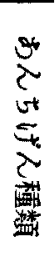 \\
\hline $\begin{array}{l}\infty \\
\text { os } \\
+4\end{array}$ & $\overrightarrow{10}$ & $\begin{array}{l}\dot{\alpha} \\
0 \\
\vec{x}\end{array}$ & $\vec{D}$ & $\begin{array}{l}+\infty \\
\infty \\
+\infty\end{array}$ & $\vec{N}$ & $\begin{array}{l}\infty \\
\infty \\
\rightarrow\end{array}$ & $\vec{n}$ & \multicolumn{2}{|c|}{$\begin{array}{l}\text { 酷 } \\
\text { 棠 }\end{array}$} \\
\hline 䒠 & $\neq$ & $\neq$ & $\neq$ & $\neq$ & $\neq$ & 圭 & $\neq$ & $\begin{array}{c}1 \\
320\end{array}$ & \multirow{5}{*}{$\begin{array}{l}18 \\
3 \\
2 \\
0 \\
5 \\
\tau \\
\tau\end{array}$} \\
\hline+ & + & $\mp$ & + & $\neq$ & $\neq$ & 䒠 & $\neq$ & $\begin{array}{c}\text { II } \\
640\end{array}$ & \\
\hline 1 & 1 & 1 & 1 & 1 & $\neq$ & 寿 & $\neq$ & $\begin{array}{c}\mathbb{1 0} \\
1280\end{array}$ & \\
\hline 1 & 1 & 1 & 1 & 1 & 1 & 1 & 1 & $\begin{array}{r}\text { IV } \\
2560\end{array}$ & \\
\hline 1 & 1 & 1 & 1 & 1 & 1 & 1 & 1 & $\begin{array}{c}\bar{V} \\
5120\end{array}$ & \\
\hline$\neq$ & $\neq$ & 末 & $\neq$ & $\neq$ & $\neq$ & 春 & 三 & $\begin{array}{c}\mathrm{I} \\
320\end{array}$ & \multirow{5}{*}{$\begin{array}{l}8 \\
8 \\
3 \\
2 \\
0 \\
\vdots \\
\tau\end{array}$} \\
\hline+ & $\neq$ & $\neq$ & $\neq$ & $\neq$ & $\neq$ & 声 & $\neq$ & $\begin{array}{c}\text { II } \\
640\end{array}$ & \\
\hline 1 & 1 & 1 & 1 & 1 & $\neq$ & $\neq$ & 辛 & $\begin{array}{c}\text { III } \\
1280\end{array}$ & \\
\hline 1 & 1 & 1 & 1 & 1 & 1 & 1 & $\neq$ & $\begin{array}{c}\text { IV } \\
2560\end{array}$ & \\
\hline 1 & 1 & 1 & 1 & 1 & 1 & 1 & 1 & $\begin{array}{c}\nabla \\
5120\end{array}$ & \\
\hline$\neq$ & $\neq$ & $\neq$ & $\neq$ & $\neq$ & $\neq$ & 烂 & 表 & I & \multirow{5}{*}{ 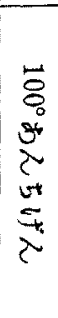 } \\
\hline+ & + & $\neq$ & + & $\mp$ & $\neq$ & F & 全 & $\underset{640}{\text { II }}$ & \\
\hline 1 & 1 & 1 & 1 & 1 & $\neq$ & + & $\neq$ & $\begin{array}{c}\mathbb{1 0} \\
1280 \\
\end{array}$ & \\
\hline 1 & 1 & 1 & 1 & 1 & 1 & 1 & + & $\begin{array}{r}17 \\
2560\end{array}$ & \\
\hline 1 & 1 & 1 & 1 & 1 & 1 & 1 & 1 & $\begin{array}{c}\nabla \\
5120\end{array}$ & \\
\hline
\end{tabular}

上表二示ス如ク加熱菌 凝集價 ル流產菌ノ被凝集性、生おんちぢん二比シ加熱あんちげんハ稍? 高ク之レ二反シもるて菌、生あんちげん二比シ加熟すんちげんい 
却ツテ被凝集性 $\exists$ 低下セり又此等血清, 兩菌凝集價 7 比較スル 第 9 號血清 生菌二於テハ同一ナルモ加熱菌二於テハ顯著ナル差

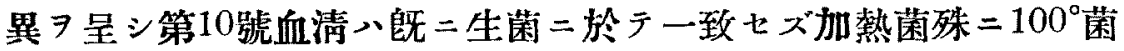
二於テ明カナル差異ヨ示セリ又加熱もるた免疫血清二對スル被凝 集性》生菌及加熱菌卜ノ間二差異ナク其凝集價モ殆ンド相一致セ リ以上ノ實驗ニヨリ流產菌免疫血清二對スル兩菌間二認ムぶキ被 凝集性，差異 $\exists$ 加熱菌免疫血清二於ラ生菌免疫血清ヨリモ一層明 カニ證明火ルコト・得タリ

\section{(d)凝集素ノ加熱二對スル影響有無}

1911年 Negrie \& Baynaud 八健康血清中二ハもるた菌化膿球菌 四駢苍菌 Sarcina tetragena 肺炎璉菌等二對シ 2 種ノ凝集素 7 含 有シ特異性ノモノメ5 $56^{\circ}$ ノ加熱二耐一非特異性ノモノ八加熱二ヨ リ消失シ且非特珙性凝集素》發熱時二增加スルヨ報告セリ仍テ以 上實驗二使用セル流產菌及るるて菌免疫血清ノ凝集素》加熱 $=\exists$ リ尜化スルャ否二就キ實驗

あんちげん、生菌

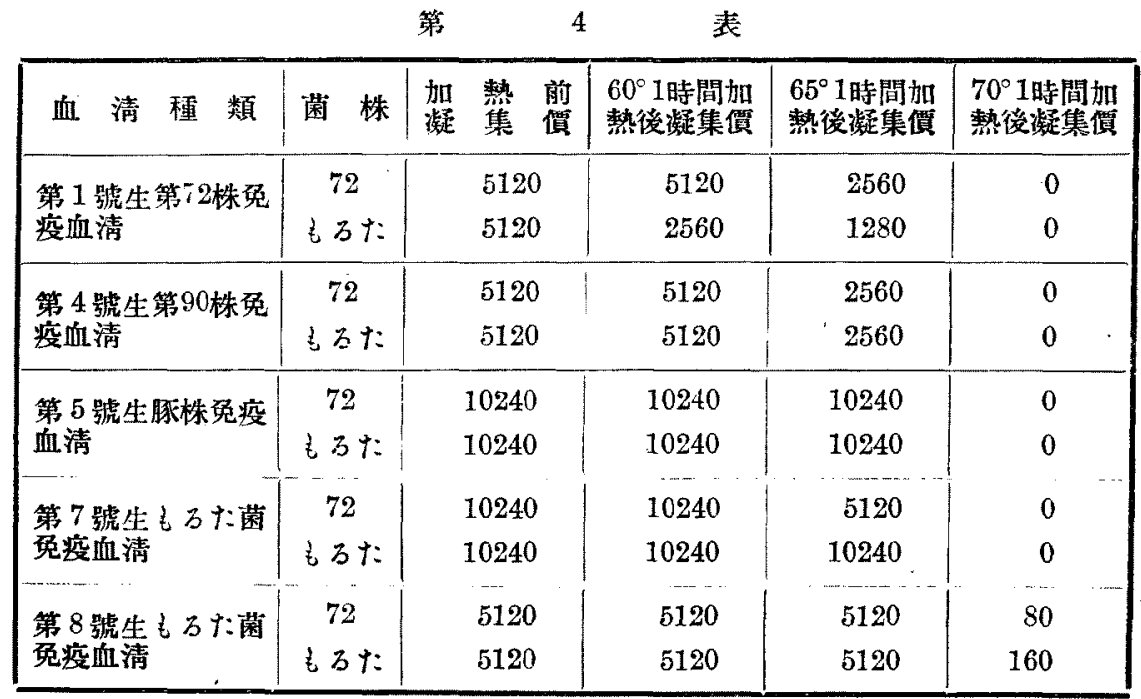


上表二示ス如ク血清 7 加㴵スルニ其凝集素り減少ハ血清, 種類 ニョリ一定セザルモ概シラ $60^{\circ}=$ 於テ 殆ント減少セズ $65^{\circ}=$ 於 テ幾分減少スルモノアルモ著シカラズ $70^{\circ}=$ 於テハ第 8 號血清 除ケバ他》全部ノ凝集素消失七り而シテ第 8 號血青心原凝集素，

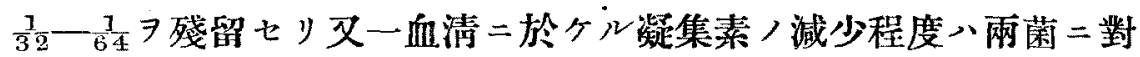
シ相本行シ特二差異ヨ認ムル能ハザリキ

\section{IV. 吸收試噞}

流產菌及まるて菌ノ注射ニョリテ發生七ル沱集素入單一,性質 ヨ有シ相均シキモノナリヤ否二就キ試驗

第

\begin{tabular}{|c|c|c|c|c|c|}
\hline \multirow{2}{*}{ Iflit. } & \multirow{2}{*}{ 清 } & \multicolumn{4}{|c|}{ あんちげス種類（生） } \\
\hline & & 72 & 90 & 豚 & もろた \\
\hline \multirow{5}{*}{$\begin{array}{l}\text { 第免 } \\
1 \text { 阌 } \\
\text { 號面 } \\
\text { 牛清 } \\
\text { 第 } \\
72 \\
\text { 株 }\end{array}$} & 吸 收 前 㠜 集 價 & 5120 & 5120 & 5120 & 5120 \\
\hline & 生算 72 株吸收後凝集簤 & 0 & 0 & 0 & 0 \\
\hline & 生第 90 株吸收後凝集傊 & 0 & 0 & 0 & 0 \\
\hline & 生豚株吸收後凝集䨘 & 0 & 0 & 0 & 0 \\
\hline & 生も万た囷吸收後㠜集價 & 640 & 1280 & 1280 & 0 \\
\hline \multirow{5}{*}{$\begin{array}{l}\text { 第免 } \\
4 \text { 疫 } \\
\text { 號血 } \\
\text { 生清 } \\
\text { 第 } \\
90 \\
\text { 株 }\end{array}$} & 吸 收 前 凝 集 價 & 5120 & 5120 & 5120 & 5120 \\
\hline & 生第 72 株吸收後凝集䤑 & 0 & 0 & 0 & 0 \\
\hline & 生第 90 株吸收後凝集㵋 & 0 & 0 & 0 & 0 \\
\hline & 生豚株吸收後凝集傊 & 0 & 0 & 0 & 0 \\
\hline & 生もった菌吸收後凝集價 & 1280 & 640 & 1280 & 0 \\
\hline \multirow{4}{*}{$\begin{array}{l}\text { 第免 } \\
5 \text { 疫 } \\
\text { 號血 } \\
\text { 生清 } \\
\text { 豚 } \\
\text { 株 }\end{array}$} & 吸 收 前 凝 集 㵋 & 10240 & - & 20480 & 10240 \\
\hline & 生策 72 株吸收後凝集價 & 0 & - & 0 & 0 \\
\hline & 生豚株吸收後凝素價 & 0 & - & 0 & 0 \\
\hline & 生当乃た菌吸收後凝集傜 & 640 & - & 0 & 0 \\
\hline \multirow{4}{*}{$\begin{array}{c}\text { 第た } \\
7 \text { 菌 } \\
\text { 號免 } \\
\text { 生资 } \\
6 \text { 血 } \\
\text { 方清 }\end{array}$} & 吸收前凝集 偪 & 10240 & 10240 & 10240 & 10240 \\
\hline & 生第 72 株吸收後凝集㙁 & 0 & 0 & 0 & 640 \\
\hline & 生第 90 株吸收後凝集價 & 0 & 0 & 0 & 640 \\
\hline & 生もるた菌吸牧後凝集㵋 & 160 & 320 & 320 & 0 \\
\hline \multirow{2}{*}{$\begin{array}{c}\text { 第 } \\
8 \text { b } \\
\text { 躆た } \\
\text { 生免 }\end{array}$} & 吸 收 前 凝 集 㵋 & 5120 & 10240 & $\longrightarrow$ & 5120 \\
\hline & 生第 72 株吸收後凝集偵 & 0 & 0 & 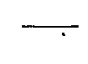 & 640 \\
\hline
\end{tabular}




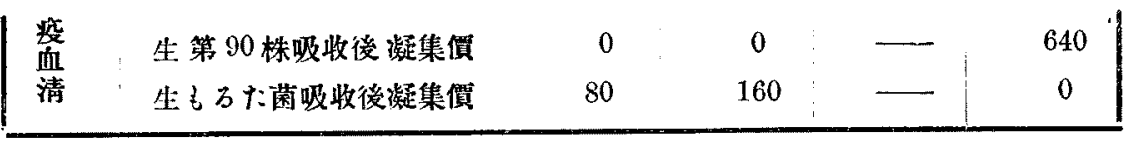

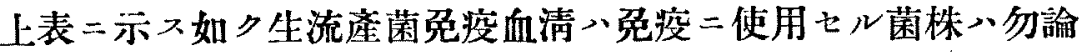
他 もるた菌二對シ反應 ル時ハるるて菌二メ全ク反應セザルモ流產菌二メ仯多量ノ凝集素 习殘留ス 即于第 1 號及第 4 號血清入血清全疑集素〉 $\frac{1}{4}-\frac{1}{8}$ 第 5 號血 清八 $\frac{1}{1 \overline{6}}-\frac{1}{3} \overline{2}$ 減少セり

又るるれ菌免疫血清い流產菌二テ吸收スル時心流産菌二對スル 凝集素》消失スルモるるれ菌二對シ全凝集素, $\frac{1}{8}$ 量 ラ同血清ヨもるけ菌二ラ吸收スル時ハもるて菌二八反㦄ヨ呈セザ ルモ何レノ流產菌株二對シテモ $\frac{1}{32}-\frac{1}{64}$ 量 7 殘セり令生流產菌又 生するて菌免疫血清中二有スル凝集素入單一ナル性質ニシテ相共 通スルモノトスレバー菌株 對シテモ反應ヨ呈セザルバキナリ然ル二前述ノ如キ結果 $コ$ 生ズル 八血清中二兩菌間二共通スル凝集素卜各特有ノ凝集素ノ存在 7 認 メザル可カラズ郎チ血清ノ有スル凝集素入其全凝集價及吸收後， 凝集價 $コ$ 計算シテ本均次記，如制合二存在スルモ，ト看做入 コトヨ得ベシ

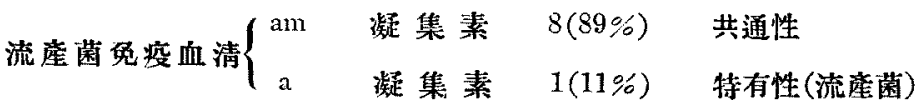

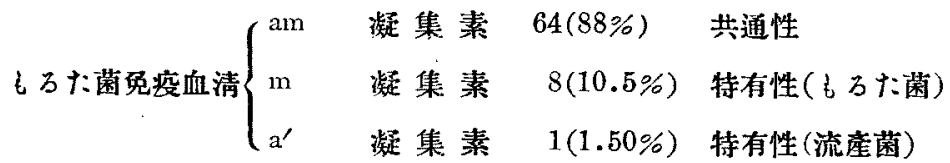

もるた菌色疫血清中二流產菌ノミ二反隹スル凝集素ガ䄪 $1.5 \%$ ノ割合二存在スルハー見奇異ノ威 $\exists$ 生ズ本血清心雨菌二對スル健 常凝集素 ヨ有セザリショ以テ該凝集素ハもるた菌泩射ニョリ發生 
セルモノナラザル可カラズ郎チるるて菌ニハ3種ノ凝集原性アリ テ之レヨ家鬼二注射スル時八各其凝集原二相當スル凝集素 スルモ其ノ一郎チ $\mathrm{a}^{\prime}$ 二該當スル疑集素二八被凝集性 アラザルヤ少多數ノ家兔二もるた菌 1 例 (第14號) 二於テ斯ル凝集素习證明セザルモノ存在セり此ノ事 實ヨリるるけ菌血清中二存在スル $\mathrm{a}^{\prime}$ 凝集素、もるけ菌注射二ヨリ 每常發生ス可キ特有ノ凝集素卜稱スル能ハザルモノ、如シ

次デ $100^{\circ} 1$ 時間加熱セル流產菌又心もるて熱菌二テ生菌免度血 清 $\ni$ 吸收セシ二單二生菌二テ吸收セシ結果卜略一致セシモ各特有 ノ凝集素 一層明カニ認ムルコトヨ得タリ

\section{A 生及 100 度加熱菌 9 以テ加熱菌免疫血清 9 吸收セル 場合}

加熱細菌二テ免疫セル血清 7 生又 $100^{\circ}$ 加熱菌二テ吸收スルニ 流座菌免疫血清，有スル疑集素》生菌免疫血清ト殆ンド相一致ス

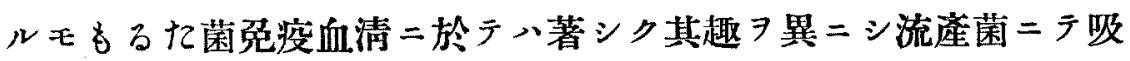
收スル時八雨菌二反隼スル殆ンド全部ノ凝集素消失シもるた菌特 有ノ疑集素 $(\mathrm{m})$ 八僅微二存在スルカ又心全ク消失ス而シテ同血清 中二存シタル流產菌特有，凝集素 $\left(\mathrm{a}^{\prime}\right) モ 大$ 部分消隇シ其存在不定 ナリ其成績い次表，如シ

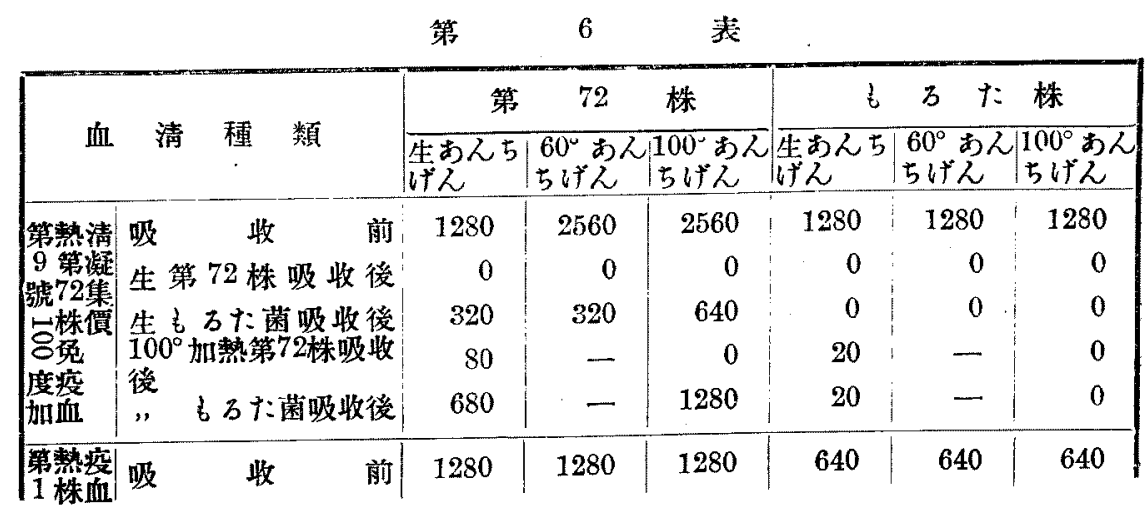




\begin{tabular}{|c|c|c|c|c|c|c|c|}
\hline 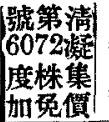 & $\begin{array}{l}\text { 生第 } 72 \text { 株吸收後 } \\
\text { 生も万た菌吸收後 }\end{array}$ & $\begin{array}{r}0 \\
320\end{array}$ & $\begin{array}{r}0 \\
320\end{array}$ & $\begin{array}{r}0 \\
320\end{array}$ & $\begin{array}{l}0 \\
0\end{array}$ & $\begin{array}{l}0 \\
0\end{array}$ & $\begin{array}{l}0 \\
0\end{array}$ \\
\hline 第熱血| & 收 & 640 & 640 & 320 & 640 & 640 & 640 \\
\hline 11 清 & 生第 72 株 吸收後 & 0 & 0 & 0 & 40 & 0 & 0 \\
\hline 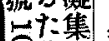 & 生々っるた菌吸收後 & 0 & 0 & 0 & 0 & 0 & 0 \\
\hline 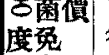 & 後 & 0 & - & 0 & 0 & - & 0 \\
\hline 加疫 & " も万江菌吸收後 & 40 & - & 0 & 20 & - & 0 \\
\hline 第熱疫 & 前 & 640 & 640 & 640 & 610 & 320 & 640 \\
\hline 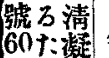 & 生第 72 株 吸收後 & 0 & 0 & 0 & 20 & 0 & 0 \\
\hline \begin{tabular}{|l} 
度菌集 \\
加免傊
\end{tabular} & 生もるた囷吸收後 & 20 & 0 & 0 & 0 & 0 & 0 \\
\hline
\end{tabular}

加熱菌 7 造抗原トスル時ハ生菌 價八著シク低シ郎チ加熱菌》造抗原トシテノ價值微弱ナルタ以テ 生るて菌血清二於テ認メタルが如手特異ノ凝集素习十分發現ス

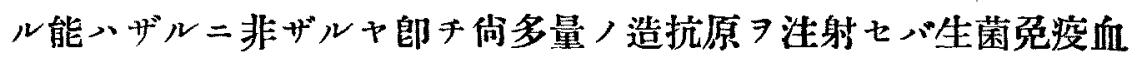
清ト均シク 3 種ノ凝集素习顯著二發現スルニ至ルニアラザルカ 仍テ 4 回二全菌量 10,0mg (生菌注射量, 100 倍) 7 注射七ル血清 (第 15 號 $100^{\circ}$ 加熱もるた菌免疫血清ニシテ寒天斜面 $=48$ 時間培 養セルモノ $フ$ 食監水乳劑卜ナシ $100^{\circ} 1$ 時間加熱シテ泩射入第

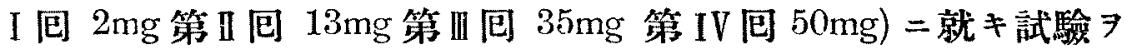
行一リ

\begin{tabular}{|c|c|c|}
\hline & 生第72株あんちげん & 生もるけ菌株あえらげん \\
\hline 第 15 號血清㠜集偵 & 1280 & 1280 \\
\hline $\begin{array}{l}\text { 同血清生第72株吸收 } \\
\text { 捘凝集偵 }\end{array}$ & 0 & 40 \\
\hline $\begin{array}{l}\text { 同血清生：万ナ株吸 } \\
\text { 收後凝集㵋 }\end{array}$ & 20 & 0 \\
\hline
\end{tabular}

上表二示ス如ク加繁菌ノ大量 $\exists$ 泩射スルモ全疑集素及各菌二對 スル特有ノ疑集素入著シク增加セズ此等ノ結果ヨリ見ル時ハ流

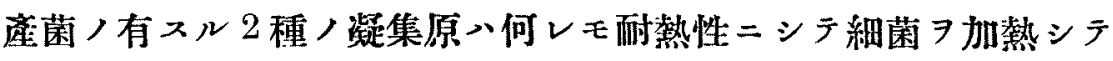
注射スルモ之レニ相當スル2種,凝集素 7 產生ス之レ二反シもる 
て菌ノ有スル３種ノ凝集原八耐熱性及非耐熱性二分タル䄪手兩菌 間二相共通スル凝集原 $(\mathrm{am})$ 加熱ニヨリ造抗原性 フ失フコトナキ モ各菌二特異二反應スル凝集原 $\left(\mathrm{m}\right.$ 及 $\left.\mathrm{a}^{\prime}\right)$ 八加熱二ヨリ大部分消失 $ス ル ニ$ 至ル此ノ結果ヨリ流產菌免疫血清二對シ加熱るるた菌ノ被 凝集性ノ減弱スルハ容易二說明スルコトヨ得心゙シ

㕛流產菌及るるて菌色疫血清 $760^{\circ}=1$ 時間加熱シタル後各雨 菌株 以ラ吸收試驗

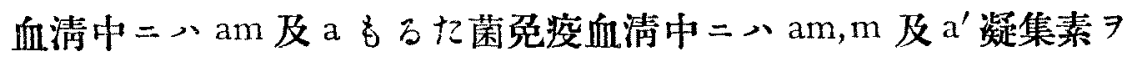
澄明七り仍テるるた菌ノ凝集原ノ一部》熱二對シ容易二破壤シテ 大部分ノ造抗原性 $フ$ 失フト踓モ之レ二相當スル凝集素》其性質 繼承スルコトナク熱二耐過スルラ知ル而シラ緒言二於テ述べタル 如ク從來行 ンレシ流產菌及るて菌ノ此較研究二於ラ吸收試驗成 績ノ一定セザリシハるるた菌凝集原性ヨ考慮スルコトナク血清製 浩方法及めんちげんノ性質 7 異ニシ且凝集素 7 吸收スルトキ添加 セル細菌量不足セシニヨルナラン

\section{V. 補體結合反應}

實驗二使用七ル材料ハ次記ノ如シ

1. 免疫血清 液集反應二使用セルモ, $756^{\circ} 30$ 分加溫シテ非働性トナシ用ニ

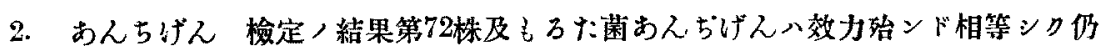
テ各 20 倍稀燡 0.5ca. 习使用セり

3. 補體もるもつと>新鮮血清 八2頭ニシテ必要二臨ミ心藏ヨリ注射器ニテ探血セルモノナり而シテ檢定ノ結果 10 倍 稀䆁 0.2c.c. 7 月月

4. 溶血性血清 糆美血球免疫血清 2.000 倍稀釋 1.0c.c. 7 用二

5. 血球液 3 四洗湺 $5 \%$ 緬羊血球 7 用二

其成績 次表/如シ 


\begin{tabular}{|c|c|c|c|c|c|c|c|c|c|}
\hline & & I & il & 清 & 稀 & 釋 & & 变 & \\
\hline & 0.05 & 0.02 & 0.01 & 0.005 & 0.002 & 0.001 & 0.0005 & 0.00020 & 0.0001 \\
\hline 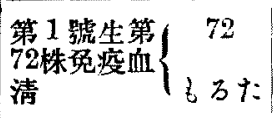 & - & - & $\begin{array}{l}- \\
-\end{array}$ & - & - & - & $\begin{array}{l}H \\
H\end{array}$ & $\begin{array}{l}\text { H } \\
H\end{array}$ & $\begin{array}{l}H \\
H\end{array}$ \\
\hline $\begin{array}{l}\text { 第 } 3 \text { 號生第 } \\
90 \text { 株免疫血 }\left\{\begin{array}{c}72 \\
\text { 清 }\end{array}\right.\end{array}$ & - & - & - & - & - & $\begin{array}{l}- \\
-\end{array}$ & $\begin{array}{l}+ \\
+t\end{array}$ & $\begin{array}{l}H \\
H\end{array}$ & $\begin{array}{l}H \\
H\end{array}$ \\
\hline 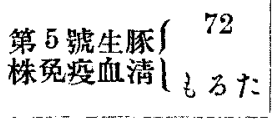 & - & $\begin{array}{l}- \\
-\end{array}$ & - & - & - & $\begin{array}{l}- \\
\pm\end{array}$ & $\begin{array}{l}+ \\
H\end{array}$ & $\begin{array}{l}H \\
H\end{array}$ & $\begin{array}{l}H \\
H\end{array}$ \\
\hline $\begin{array}{l}\text { 第 } 7 \text { 藘生も } \\
\text { 万た囷急疫 } \\
\text { 血清 }\end{array}$ & - & - & - & $\begin{array}{l}- \\
-\quad \\
-\end{array}$ & - & - & $\begin{array}{l}+ \\
-\end{array}$ & + & $\begin{array}{l}H \\
H\end{array}$ \\
\hline 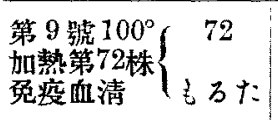 & - & - & \pm & $\begin{array}{l} \pm \\
H\end{array}$ & $\begin{array}{l}\mathrm{H} \\
\mathrm{HH}\end{array}$ & $\begin{array}{l}H \\
H\end{array}$ & $\begin{array}{l}\text { H } \\
\mathrm{HH}\end{array}$ & $\begin{array}{l}\mathrm{HH} \\
\mathrm{HH}\end{array}$ & $\begin{array}{l}H \\
H\end{array}$ \\
\hline 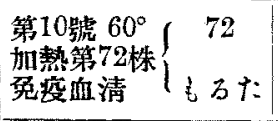 & - & - & - & $\begin{array}{l}+t \\
H\end{array}$ & $\begin{array}{l}\text { H } \\
H\end{array}$ & $\begin{array}{l}H \\
H\end{array}$ & $\begin{array}{l}H \\
H\end{array}$ & $\begin{array}{l}\text { H } \\
H\end{array}$ & $\begin{array}{l}\text { H } \\
\text { H }\end{array}$ \\
\hline 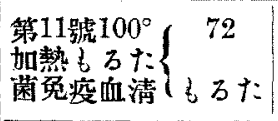 & - & $\begin{array}{l}H \\
+\end{array}$ & $\begin{array}{l}H \\
H\end{array}$ & $\begin{array}{l}H \\
H\end{array}$ & $\begin{array}{l}H \\
H\end{array}$ & $\begin{array}{l}H \\
H\end{array}$ & $\begin{array}{l}H \\
H\end{array}$ & $\begin{array}{l}H \\
H\end{array}$ & $\begin{array}{l}H \\
H\end{array}$ \\
\hline 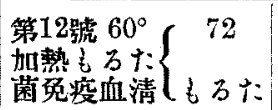 & - & $\begin{array}{l}+t \\
+t\end{array}$ & $\begin{array}{l}H \\
H\end{array}$ & $\begin{array}{l}H \\
\mathrm{Hif}\end{array}$ & $\begin{array}{l}H+ \\
H\end{array}$ & $\begin{array}{l}\text { H } \\
H\end{array}$ & H & $\begin{array}{l}H \\
H\end{array}$ & $\begin{array}{l}H \\
H\end{array}$ \\
\hline
\end{tabular}

上表二示ス如ク各血清ノ補體結合價い大體相一致セり然レドモ 仔細二比較スル時》流產菌免疫血清》流產菌二もるけ菌免疫血清

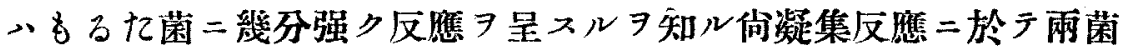
ノ產生セル凝集素い單一ナル性質ニアラザルタ認タリ仍テ補體結 合素ニモ之レヨ認ムル能ハザルャヨ思ヒ次ギノ試驗

A 免疫血埨中二各あんちげん=特有ノ補體結合素 $ᄏ$ 有 セザルヤ

兩菌あんちげん 120 倍稀釋 0.5c.c. 71 容トナシ 其牛量郎チ 0.25 C.C. $7 \frac{1}{2}$ 容トナシ一定血清 75 列二遞減稀䆁シ之レニあんちげんノ 
種類及分量 $习$ 異ニシテ加一反隹結果 $习$ 對比セり

第 8 表

\begin{tabular}{|c|c|c|c|c|c|c|c|}
\hline \multirow{2}{*}{$\begin{array}{l}\text { 血清 } \\
\text { 種類 }\end{array}$} & \multirow{2}{*}{$\begin{array}{l}\text { お人5げん種類及 } \\
\text { 分量 (容) }\end{array}$} & \multicolumn{2}{|c|}{ 血 } & \multicolumn{2}{|c|}{ 稀 } & \multicolumn{2}{|c|}{ 度 } \\
\hline & & 0.01 & 0.005 & 0.002 & 0.001 & 0.0005 & 0.0002 \\
\hline \multirow{5}{*}{ 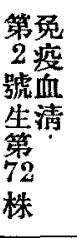 } & \multirow{2}{*}{ 72おんちげス } & - & - & - & H & H & $H$ \\
\hline & & - & - & $t+$ & $\mathrm{HH}$ & HH & 册 \\
\hline & \multirow{3}{*}{ 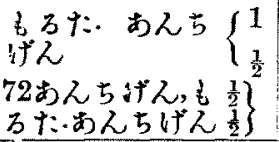 } & - & - & $H$ & \# & $H$ & Ht \\
\hline & & - & $t+$ & $H$ & $H$ & $H$ & $H$ \\
\hline & & - & - & - & \pm & \# & H \\
\hline \multirow{5}{*}{ 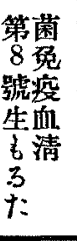 } & \multirow{2}{*}{ 72あんちげん } & - & - & - & $H$ & H & 世 \\
\hline & & - & - & \pm & $\mathrm{HH}$ & H & 世 \\
\hline & \multirow{2}{*}{ 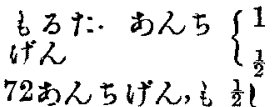 } & - & - & - & \pm & $H$ & HH \\
\hline & & - & - & + & $H$ & H & i\# \\
\hline & 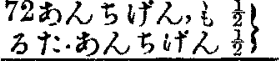 & - & - & - & \pm & H & H \\
\hline
\end{tabular}

以上ノ實驗ハ再三反復セシニ大體二於テー致セル結果 7 得タリ 流迹菌血清 流産菌あんちげんヨ添加セル容量二應 ジとレ二相當 スルもるて菌あんちげん二此シ强キ補體結合價 ヨ示セリ而シテ雨 菌あんちげん习等分二混合シテ用ュル時八單一二あんちげんヨ加

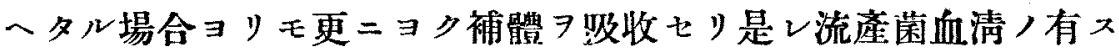
ル補體結合素ハ流產菌あんちげん卜結合スル場合二多量ノ補體 必要卜スルモ，ナリャ(1) 又八血清中二もるて菌二反應七ザル流 產菌特異ノ結合素ヨ有スルニアラザルヤ (2) 且流產菌血清中二ハ 特ニもるれ菌あんちげん二對シ强キ結合性 7 有スル補體結合素 モ一部含有スルニアラザルヤ(3) 又もるけ熱菌免疫血清小もるた 菌あんちげん二對シ幾分强ク反應ス而シテ雨あんちげん习混合ス

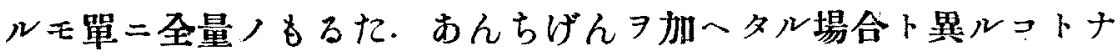

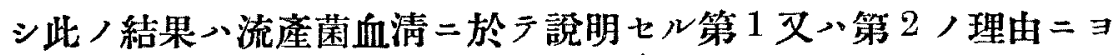
リテ生ゼシモノト認メザル可カラズ仍ラ先ヅ一定血清中二於ケル 兩あんちげんノ補體消費量 檢查スルコト・セり 


\section{a 補體消費量}

一般二補體結合反應二使用スルおんちげん量《補體ノ作用 7 防 止セザル程度ノ大量ニシラ必要量以上二添加スルモノナリ跑ッテ 補體吸收量 檢スルニハ此ノ量ニテハ不適當ナルヨ以テ先ヅ一定 血清二對スルあんちげんノ有效量 ヨ計ラザル可カラズ

\section{c あんちげんノ效力}

實驗二使用七ルあんちげん入製造後 6 筒月⿻經過セルモノニシ テ帶黄色唀明性 7 有 $又$ 檢定ノ結果 0.1c.c. 二於テ全ク 0.08c.c. 二於テ 多少補體/作用 $习$ 防止シ完全ナル血球溶解习起サズ 0.05c.c以下 於于血球 7 完全二溶解セり仍于あんちげんハ0.05c.c.上７階段的 二稀釋シテ比較スルコト、セリ又血清、次, 如キ量 3)

第 2號生第72株免疫血清

第 8 號生しろけ菌免疫血清

補體

溶 血 系
$0.01 \mathrm{ccc}$ (10 倍稀釋 0.1c.c.7 用二)

0.002 c.c. (50 倍稀釋 0.1c.c. 7 月ュ)

$0.02 \mathrm{ccc}$ (10 倍桸翠 $0.2 \mathrm{c.c} .7$ 用二

第V項二述べタルト等シ

第 9 表

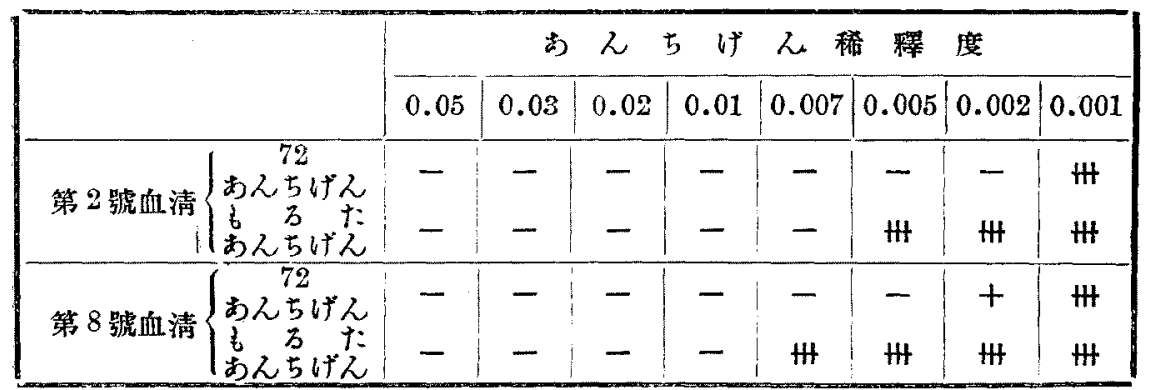

此ノ結果ヨリ流虐菌あんちげんノ最低有效量、第2 號血清二於 テハ0.002c.c. 第 8 號血清二於テハ0.005c.c もるて菌すんちげんノ 最低有效量、第 2 號血清二於テふ0.007c.c 第 8 號血清二於テハ0.0 1c.c.ナリ仍テあんちげんふ各最低量，倍量 7 使用スルコト、セリ 
䬦于

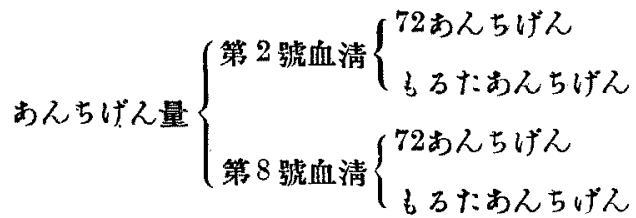
100 倍稀釋 $0.4 \mathrm{cca}$
20 倍稀釋 $0.28 \mathrm{ca}$
40 倍稀釋 $0.4 \mathrm{ca}$
20 倍稀釋 0.4c.c

血. 清 量 $\left\{\begin{array}{lll}\text { 第 } 2 \text { 號血清 } & 10 \text { 倍稀釋 } & 0.1 \text { c.c. } \\ \text { 第 } 8 \text { 號血清 } & 50 \text { 倍稀䆁 } & 0.1 \text { c.c. }\end{array}\right.$

補體八 0.01 c.c. (10倍稀釋 0.1 c.c.) ニテ完全ナル溶解作用ヨ有セショ以テソレヨリ以上 ᄏ階段的二霓量使用又

溶血系第 V垻二等シ

其成績八次表，如

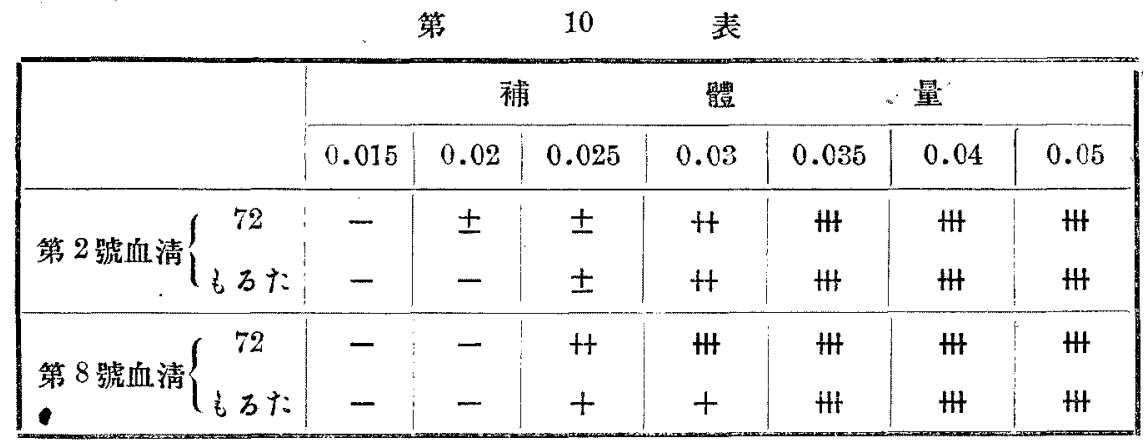

上表二示ス如ク兩種血清二於ケル成續、一致シ流產菌あんちげ んハもるて菌あんちげん二比シ補體ノ消費量僅少ナル テ前記ノ第 1 二揭グシ理由心容易二否定スルントヨ得タリ然ラバ 流產菌血清二八吸收反應, 場合二證明七シ成績ト均シク補體結合 反磪二於テモ又るるて菌二比シ多量ノ流產菌補體結合素ノ存在 認メザル可カラズ而シテ第 3 理由以成立スルヤ否い單二此ノ實

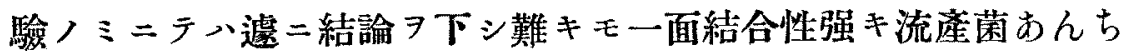
げんト補體沙費量多きするた菌おんちげんトノ混和ハもるた菌特 異ノ補體結合素ヨ要セズシテ斯ル强反隼ヨ呈スルニアラザルカ塊 チ吸收反應等ノ結果ヨリ總合シラ考フルニ恐ラク此ノ解釋ヨ至當 
トスベシ又もるて菌血清いるるて菌あんちげん二對シラ幾分强ク 反應スルン血清中二同あんちげん二對シ强キ漞和力 $ヨ$ 有スル補體 結合素ヨ含有スルト認ムルョリモ寧口該あんちげん以補體ヨ强ク 吸收スル 以テ斯ク，如キ少量ノ差異、わんちげんノ性質ニヨル

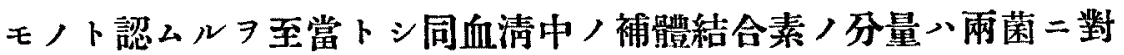
シテ差異 ヨ有セザルモノナラン

一般二あんちげん，效力八其製造方法及血清量等=ヨリ一定セ ザルモ前述二示ス如ク流產菌あんちげんハもるた菌すんちげんヨ リモ数力强ク又一定血清及おんちげん二於ケル補體ノ吸收量、も るて菌二比流產菌あんちげん八微弱ナリ此，事實モ又雨菌間ノ 性質ノ一部ノ差異ト認ムルコトヨ得ベシ

\section{VI. 沈澱反應}

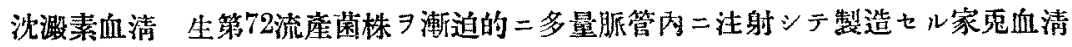

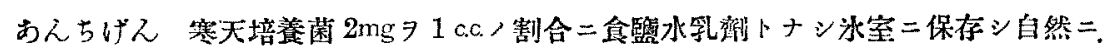
練菌ノ沈下シラ透明トナリシモ,

實驗方法 あんちげんヨー定度二稀釋シテ其容量 $0.5 \mathrm{ccc}$ トナシ之レ二前記血清 0 .

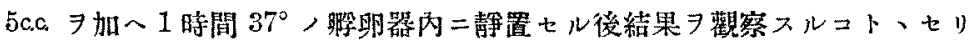

其成績八次表八如シ

第 11 表

\begin{tabular}{|c|c|c|c|c|c|c|c|c|c|}
\hline \multicolumn{4}{|c|}{ むんらげん稀釋度 } & 2 & 4 & 8 & 16 & 32 & 64 \\
\hline 第 & 7 & 2 & 株 & $H$ & $H$ & $H+H$ & $\mathrm{Ht}$ & + & - \\
\hline 第 & 9 & 0 & 株 & HH & $\mathrm{HH}$ & $\mathrm{HH}$ & + & - & - \\
\hline 豚 & & & 株 & $H$ & $\mathrm{HH}$ & $\mathrm{H}$ & $\mathrm{HH}$ & - & - \\
\hline$t$ & b & $t:$ & 菌 & $H$ & \# & $H$ & \pm & - & - \\
\hline
\end{tabular}

上表ノ如ク各菌株間二差異ヨ認ムル能ハザリキ

\section{VII, 結 論}

1. 流產菌及も万て菌免疫血清、生流產菌又心生るた菌二對 


\section{シ相等シキ凝集價 7 有入}

2. あんちげんヨ加熱シテ凝集反應 ヨ行フ二流產菌免疫血清、 流產菌二强クもるて菌二弱ク反應入此/差異八加熱菌 7 造抗原卜 シテ造レル血清二於テ特二顯著二認ムルコトヨ得もるた菌免㾤血. 清ニハ斯ル差異

3. 吸收試驗ノ結果各血清ノ有スル凝集素ハ次ギ，如ク考フル $コ ト \exists$ 得

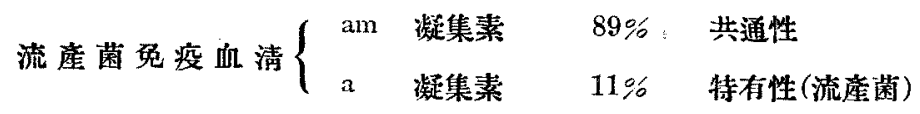

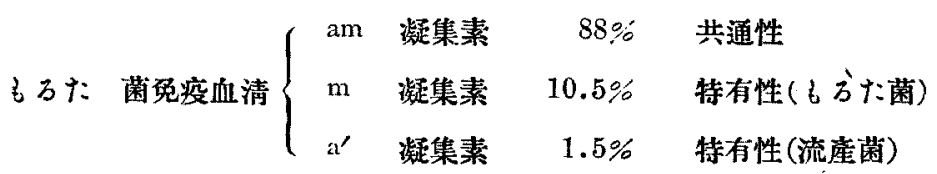

流產菌ノ有スル am 及 a 凝集原以的熱性ニシテ動物二泩射セ心 そレニ相當スル凝集素ヨ産生スるるけ熱菌ノ有スル am 凝集原八 “耐熱性ナルモ $\mathrm{m}$ 及 $\mathrm{a}^{\prime}$ 凝集原 非耐熱性二シラ加熱二ヨリ大部分消 失シ動物二注射スルモ殆ンド造抗原性 集原、耐熱性及非耐熱性二區分スルコトヨ得

4. 流產菌及もる亿菌免疫血清, 兩菌二對スル補體結合價、略 相等シキモ仔細二檢スル時心各同名あんちげん二對シ幾芀强ク反 焽不殊二流產菌血清中二八流產菌おんちげん二對シ特二强キ結合 性ヨ有スル補體結合素 7 認么

5. 流產菌あんちげん》るるて菌あんちげん二比シ常二效力强 ク又補體ノ吸收量僅少ナリ此ノ差異モ又兩菌間ノ一部ノ區別卜認 么

6. 沈澱反應二於テハ兩菌間二全ク差異ナシ

7. 豚流產菌い本邦二於テ牛ヨリ分離セル流產菌株ト何レノ點 二於テモ差異 見出ス能ハズ 


\section{8. 以上ノ實驗成績ヨリるて菌ハ流產菌ノ一異型菌ト認么}

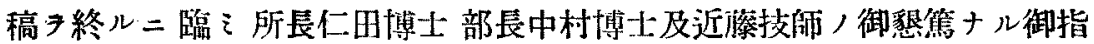

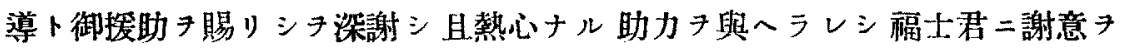
表入

\section{引用書目}

1) Alice E, Evans: Jour. Inf. Dis. Vol. 22, 1918.

2) Meyer \& Shaw: Juur. Inf. Dis. Vol. 27, 1920.

3) Fensier \& Meyer: Ditto.

4) Meyer, Shaw \& Fleischner: Jour. Inf. Jis. Vol. 31, 1922.

5) Skaric: Zeitschr. für Hygiene und Infert. 95. B., 3. Heft, 1922.

6) Zeller: $\quad B . T . W . \mathrm{Nr} .30,1920$.

7) Khaled: Joutr: Hygiene. Vol. 20, No. 4, 1921.

8) Fleischner, Vechi, Shaw, \& Meyer: Jour. Ing. Dis. Vol. 29, No. 6, 1921.

9) Bassett-Smith: Brit. Med. Jour. No. 3228, 1922.

10) Kolle \& Hetsch: Die Exp. Bact. und die Infect. mit besonderer Berück. der Immun. 1. B., 1919.

11）渡邊義政：細菌學雜誌. 第 313 號. 大正 10 年.

12）杉田卵吉：同上 第 317 號. 大正11 年.

13）松下形貞二：免废學. 大正 5 年.

14）福田, 二村：獸疫調查所研究報告. 第 1 號. 7 年

ON THE SEROLOGICAL DIFFERENCIATION OF B. ABORTUS AND B. MEIITENSIS.*

Hikojiko Futamura.

(From the Veterinary Laboratory, Ministry of Agriculture and Commerce, - Nishigahnra, Toyko, Prof. N. Nitta, Director.)

A. E. Evans (1918) demonstrated that B. abortus and $B$. melitensis are hardly distinguishable either by morphological, biochemical or serological reactions. Later, Meyer \& Shaw, Feusier \& Meyer, Zeller, Khaled and Skaric tried to differentiate them again and confirmed that they are closely allied to each other in morphological and biological characters, but in serologica reaction they are not quite identical. Feusier \& Meyer stated

* Received for publication, May 21, 1924. 
that they can generally be divided into four groups if an absorption test is applied.

Khaled noticed, furthermore, that, while they are in a fair agreement with each other as to the absorbing power for agglutinins from the anti-melitensis serum, the anti-abortus serum absorbed by $B$. melitensis losts its power to agglutinate it, but agglutinins for $B$. abortus still remain. For this reason, he suggested that the $B$. melitensis should be listed under the subdivision of the $B$. abortus.

Skaric suggested that the anti-serum prepared with one of these organisms has not only a single agglutinin, but also a compound agglutinin.

Thus it has been generally recognized that both organisms are identical with regard to their biological characters, but when the absorption test is applied, the results do not agree to the same effect. With 20 strains of $B$. abortus which were isolated from the infected materials of cattle in this country and 2 strains of $B$. melitensis and $B$. abortus from hog which were brought here from England by Dr. Nakamura, I have carried out some experiments with the view of establishing all what was stated by those investigators cited above. The results obtained are summarised as follows:-

1. It is difficult to differentiate B. abortus from B. melitensis morphologically as biochemically.

2. Either of the anti-serums prepared with these organisms have an identical agglutination titer for the both living organisms.

3. If an antigen heated, at $60^{\circ}$ or $100^{\circ} \mathrm{C}$. for an hour is used, then the anti-abortus serum agglutinates $B$. abortus more powerfully than $B$. melitensis. It seems to be most probable that, when the anti-abortus serum prepared with the heated antigen is the anti-melitensis serum does not show any difference in serological reaction.

4. The absorption test indicates that the agglutinins seem to be present in the immune serum in the following ratio.

$$
\text { Anti-abortus serum } \begin{array}{ll}
\text { Common agglutinin (AM) } & 89 \% \\
\text { Specific agglutinin (A) } & 11 \%
\end{array}
$$


Anti-melitensis serum $\left\{\begin{array}{lr}\text { Common agglutinin }(\mathrm{AM}) & 88 \% \\ \text { Specific agglutinin }\left\{\begin{array}{l}(\mathrm{M}) \\ \left(\mathrm{A}^{\prime}\right)\end{array}\right. & 10.5 \% \\ \mathrm{~A} & 1.5 \%\end{array}\right.$

A number of experiments show that the agglutinogens for $A M$ and $A$ are stable against heat and those for $M$ and $A^{\prime}$ are so labile that they lost to a great extent their antigenic power by heating. It may be seen morever, that $B$. melitenisis has two kinds of agglutinogen which differ from those of $B$. abortus.

5. In the complement fixation test there is no difference between these two organisms but the antigenic power of $B$. abortus appears more powerful.

6. That the abortus antigen has always stronger antigenic power than the melitensis antigen, will be an aid in the differentiation of both organisms.

7. No difference between these two organisms could be found in the precipitin reaction.

8. No difference was found between $B$. abortus isolated from hog and that obtained from cattle.

9. From the foregoing, $B$. melitensis may be regarded as a heterogenetic strain of $B$. abortus. 